\title{
Improving English Spoken Skills through Self Recorded Video for Higher Education Students
}

\author{
Nita H. Koesoemah \\ Department of English, Politeknik Negeri Bandung \\ Bandung, Indonesia \\ E-mail: nita.henita@polban.ac.id
}

\begin{abstract}
The research is aimed to analyze the improvement of English speaking skills for higher education students by means of Self Recorded Video. The focus of this research is on four speaking skill categories; Pronunciation, Vocabulary, Grammar and Fluency. The recorded videos are analyzed.To get the answer of the aims, descriptive method is used. The data is students' self recorded videos which were done in one semester (semester 1). The result obtained is that practising speaking English through self-recorded video can improve student speaking skills. The improvement can be in one or more categories.
\end{abstract}

Keywords: fluency, self-recorded video, descriptive method

\section{INTRODUCTION}

To prepare the students in facing their study and their career, all Bandung State Polytechnic studentsare give general subjects, including English. English for engineering departments is given in two semesters that is General English which is given either in the first or third semester and Technical English, given either in the second or fourth semester. The focus of General English is on Speaking Skills. One of the aim is to prepare the students in dealing with the job after they graduate since many big companies, especially international ones conduct their interviews in English and through the interviews, the company decides whether to hire or take the applicants to the next steps or to stop them (not to hire them). Zaremba (2006) statesthat in company recruitments, communication skill is considered more important than experience, motivation, or academic achievement.Without the ability to speak English, it will be hard for the applicants to get the job they are dreamed of. As English lecturers, we can do something for them. 


\section{LITERATURE REVIEW}

After learning English for more than ten years, from elementary to highschool, many students still have problems with their English, including spoken English. This becomes a challenge for English lecturers to improve their English, to make them fluent in speaking English. Raine (2011) states that the wordfluencycovers the four basic language skills, those are Speaking, Listening, Reading and Writing, but fluency is closer to speaking skill. Along with the idea, Gillis (2013) and Raine (2011) agree thathaving agood ability of spoken English can support them in their career so that the ability to speak needs to be improved and Patil (2008) says that it is the job of the lecturer to improve the students self confident by giving them tasks that can make them feel comfortable in using the language.

Having not enough self confidence and being afraid of making mistakes lead to Inability to speak English after learning English for years, Trent (2009). The obstacle for foreign language learners is that they do not have enough exposure to use the foreign language outside the class, moreover to use it with the native speakers, or there is just a smallchance to be a member of international community(Zhang, 2009).

Practice is one of the keys to improve speaking skill. The word speaking practice is often associated with the involvement of some people, at least, two. When the students who do not have enough self confidence have to practice their English with other persons, they will feel uncomfortableas Hughes (2010) states that speaking is different fromwriting that in speaking we donot compose and edit what we are going to utter. He furthermore says that speaking is risky because we cannot edit what we have produced. When we edit it, what we have produced stay. To solve the problem, the students can practice by themselves.

The benefit of self practice is the sudent can practice speaking by him/herself. Video recording can be used as a media as it can enrich learning practice in the era of technology.McNulty and Lazarevic (2012)state that the use of thetechnology of video can support second language learning. It is the media to do self reflect, analyze language problems and lecturers can identify students' learning improvement.FurthermoreHunter (2012) believes that Small Talk methodology is a good way to motivate learners to improve their speaking accuracy and fluency. This can be done individually or in 
groups. To start with, learners can start by self video recording the topics they are familiar with, such as"Tell me about yourself" as it can boost their self confidence.The topics can be provided eitherby the lecturers or the students. The topics provided by the students may help them study to their comfortability and level.

The video recording can be done anytime and anywhere and according to Robertson (2009), to improve English, the students have to practice three times a week. In the process,along with lots of practice the students speaking ability,their self confidence improved so that they do not feel hesitate to talk in English to other people, at least about the topics they learn.

\section{METHODOLOGY}

The method used in the research is qualitative research and the lecturer acted as the researcher. As Merriam (2009) states that in qualitative research, the reserarcher tries to find out how they explain their experience, how they shape the world, and identify their experiences.Qualitative research is a research used to get the meaning, reasons, opinions, and motivation. The sample is usually small in number, and the repondents are chosen tofulfill the quota (De Frazo, 2011).This research was to explore qualitatively the implementation and the result of the students' self recorded videoin the self learning process.

The class the researcher taught has English subject once a week, two hours in one session. To improve their English, the students have to reliaze that they need more time to practice.They do not have to take an English course, they can practice with their friends, try to communicate in English outside the class in their breaktime. This can be done if the students have enough self cofidence and do not afraid of making mistakes. Unfortunately only some have this quality. In this case self recorded video is a good way to practice speaking English.

From the beginning of the semester, the lecturer asked every student to make a video, at least once a week. In the video, the students talked about various topics the students learned such as introducing themselves, giving direction, andthe topics on mechanical engineering. This tasks were given to make them practice English by themselves and make them able to speak Ennglish.To motivate them, the videos were 
counted as their additional scores. The videos were taken using the students' phones and collected in CDs. In one semester, the students made 22 to 26 times self recorded videos

From 32 students' videos, the lecturer as the researcher took3 students' videos consisting 70 videosto be analysed.The three students' videos were chose since they talked in their videos in longer times that others. This was done to make the data able to be analysed in the rubric so that the result can be pictured out.From the three students' videos, the shortest duration is 0.20 minutes (one student made it and only once) and the longest duration is 3.04 miutes (one student made it but only once) the duration of the rest of the videos are between 0.20 to 3.04 minutes.

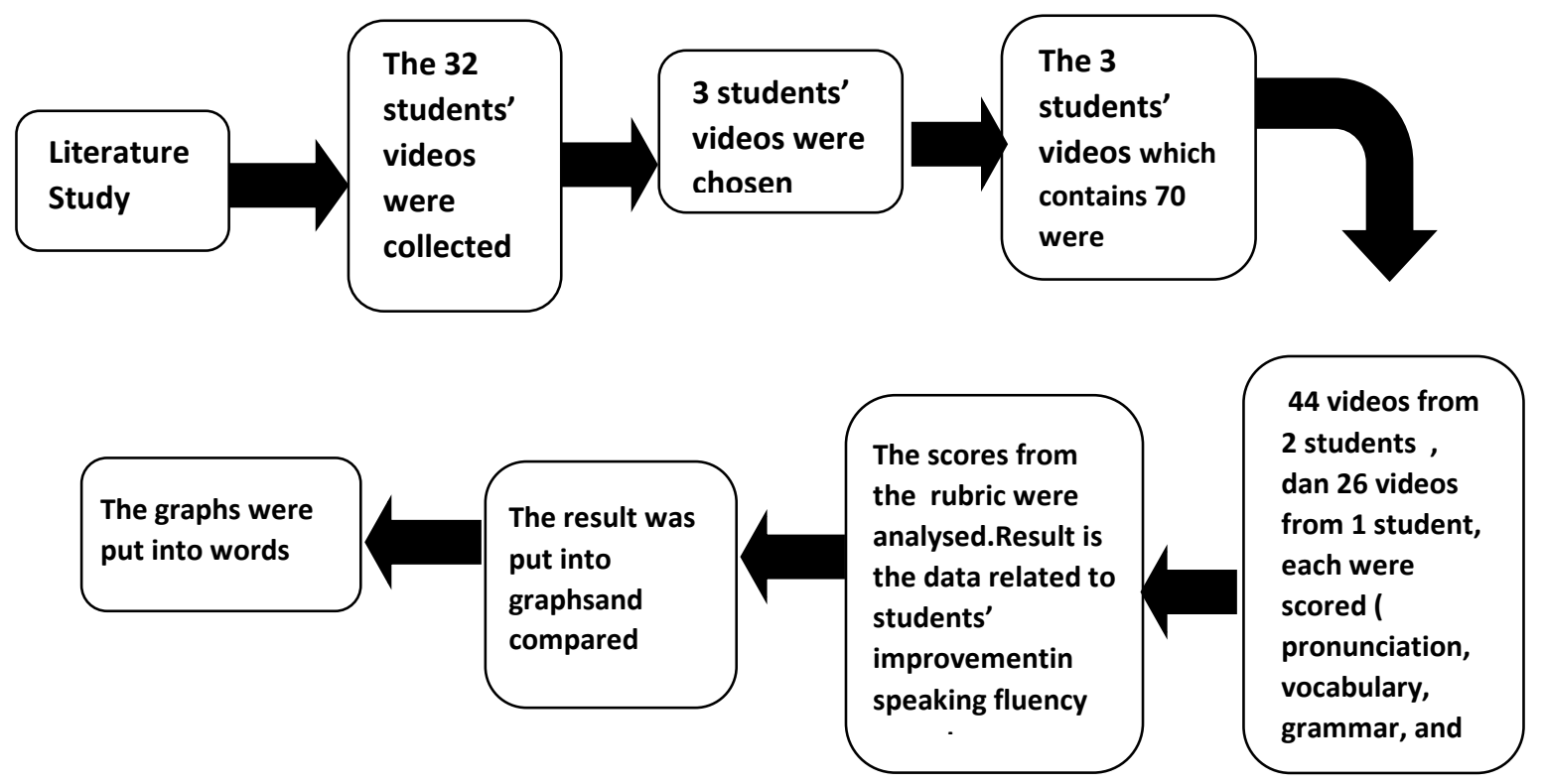

Figure 1 The schema of the research

The data was processed based on Verner's rubric in How to Evaluate Speaking. According to Verner(2017), the lecturer can evaluate students speaking skills through rubric,a tabelconsists of category columns in even numbers (the easiest is four columns).The first column is the category (Pronunciation, Vocabulary, Grammar, and Fluency). The other four columns are the score Scales (Need Improvement, Fair, Good, and Very Good). Those columns show the students speaking skills in each level. From the scores, we can identify students' level. 
Table 1 The rubrics

\begin{tabular}{|c|c|c|c|c|}
\hline The category & $\begin{array}{c}\text { Need } \\
\text { Improvement } \\
(1 \text { points })\end{array}$ & $\begin{array}{c}\text { Fair } \\
\text { (2 points) }\end{array}$ & $\begin{array}{c}\text { Good } \\
\text { (3 points) }\end{array}$ & $\begin{array}{c}\text { Very Good } \\
\text { (4 points) }\end{array}$ \\
\hline Pronunciation & $\begin{array}{l}\text { Hard } \\
\text { tounderstand, too } \\
\text { much silent, } \\
\text { unclear } \\
\text { pronunciation }\end{array}$ & $\begin{array}{l}\text { Sometimes } \\
\text { unclear, but } \\
\text { generally good. }\end{array}$ & $\begin{array}{l}\text { Good } \\
\text { pronunciation, } \\
\text { do not didsturb } \\
\text { the clarity of } \\
\text { the words. }\end{array}$ & $\begin{array}{l}\text { clearly } \\
\text { articulated } \\
\text { words }\end{array}$ \\
\hline Vocabularly & $\begin{array}{l}\text { Lack of } \\
\text { Vocabularly to } \\
\text { express ideas, lots } \\
\text { of pause to think }\end{array}$ & $\begin{array}{l}\text { Able to use } \\
\text { production } \\
\text { vocabularly to } \\
\text { some extent } \\
\text { but still } \\
\text { repeating the } \\
\text { same words } \\
\text { and cannot } \\
\text { talk more } \\
\text { about ideas. }\end{array}$ & $\begin{array}{l}\text { use specific } \\
\text { vocabulary } \\
\text { instructed in the } \\
\text { semester.Use } \\
\text { vocabulary } \\
\text { appropriate to } \\
\text { the contexts in } \\
\text { which they are } \\
\text { speaking. level } \\
\text { of vocabulary } \\
\text { Able to produce } \\
\text { good level of } \\
\text { vocabulary } \\
\text { without } \\
\text { prompting they } \\
\text { are performing } \\
\text { in this area. }\end{array}$ & $\begin{array}{l}\text { Wide variety } \\
\text { of vocabulary, } \\
\text { accurate, } \\
\text { impressive use } \\
\text { of vocabulary, } \\
\text { use the } \\
\text { vocabulary } \\
\text { learned inside } \\
\text { and outside } \\
\text { class. }\end{array}$ \\
\hline Grammar & $\begin{array}{l}\text { Have difficulties } \\
\text { to express ideas } \\
\text { caused by } \\
\text { grammatical } \\
\text { errors }\end{array}$ & $\begin{array}{l}\text { Able to express } \\
\text { ideas but with } \\
\text { unconsintent } \\
\text { structure and } \\
\text { tenses. }\end{array}$ & $\begin{array}{l}\text { Able to express } \\
\text { ideas well but } \\
\text { often make } \\
\text { error in the } \\
\text { tenses, able to } \\
\text { correct them, } \\
\text { though }\end{array}$ & $\begin{array}{l}\text { Able to } \\
\text { express ideas } \\
\text { easily } \\
\text { In good } \\
\text { structure and } \\
\text { tenses. }\end{array}$ \\
\hline Fluency & $\begin{array}{l}\text { Very slow speech, } \\
\text { nervous and } \\
\text { unsure. Short } \\
\text { expressions. Hard } \\
\text { for listeners to } \\
\text { understand. }\end{array}$ & $\begin{array}{l}\text { Slow speech } \\
\text { and often } \\
\text { unsure.Some } \\
\text { sentences are } \\
\text { not complete, } \\
\text { but able to } \\
\text { continue }\end{array}$ & $\begin{array}{l}\text { Able to produce } \\
\text { a speech that is } \\
\text { almost perfect } \\
\text { but sometimes } \\
\text { there is a kind } \\
\text { of hesitationand } \\
\text { do ot run } \\
\text { smoothly. This }\end{array}$ & $\begin{array}{l}\text { Almost all the } \\
\text { speech is like } \\
\text { or close to } \\
\text { native } \\
\text { speaker. }\end{array}$ \\
\hline
\end{tabular}




\begin{tabular}{|l|l|l|l|l|}
\hline & talking. & $\begin{array}{l}\text { may be caused } \\
\text { bychanging or } \\
\text { trying to find } \\
\text { the words. }\end{array}$ & \\
\hline
\end{tabular}

All of the self recorded videos of the three students were put into the rubric and the pronunciation, vocabulary, grammar, and fluency are scored. Each categry has four four points, they are: one points (Need Improvement), two points (Fair), three points (Good), and four points (Very Good). Each video of each student was given a point (from one to four points) in each category. The highest point is sixteen points while the lowest is four. The scoring result was then transfered into a graph so that the result can be seen clearly, whether there was an increase, decrease, or no change after the student practiced English through self recorded video.

\section{RESULTS AND DISCUSSION}

The recordings of the three students scored in points and put the score into the tabel. Fisrt the duration, then the rubric and finally, the scores were put into the tabel. The tables with the scores were then transferred into graphs. See the tables below.

Table 2 The 22 videos'duration of student 1

\begin{tabular}{|l|c|c|c|c|c|c|c|c|c|c|c|}
\hline Video & 1 & 2 & 3 & 4 & 5 & 6 & 7 & 8 & 9 & 10 & 11 \\
\hline Duration & 0.36 & 1.11 & 1.01 & 1.09 & 0.51 & 2.17 & 2.01 & 3.04 & 2.08 & 2.38 & 2.32 \\
\hline
\end{tabular}

\begin{tabular}{|l|l|l|l|l|l|l|l|l|l|l|l|}
\hline Video & 12 & 13 & 14 & 15 & 16 & 17 & 18 & 19 & 20 & 21 & 22 \\
\hline Duration & 2.19 & 2.48 & 2.04 & 2.00 & 1.50 & 1.26 & 1.48 & 1.16 & 1.23 & 2.47 & 2.17 \\
\hline
\end{tabular}

The first number indicates minute, the numbers after point indicates second. e.g: 0.36 (36 seconds); 1.01 ( 1 minute, 01 second) 
Table 3 The example of the videos in the rubric

Video 2

Video 3

\begin{tabular}{|l|r|r|r|r|l|c|c|c|c|}
\hline The Cagories & $\begin{array}{c}1 \\
\text { point }\end{array}$ & $\begin{array}{c}2 \\
\text { points }\end{array}$ & $\begin{array}{c}3 \\
\text { points }\end{array}$ & $\begin{array}{c}4 \\
\text { points }\end{array}$ & The Cagories & $\begin{array}{c}1 \\
\text { point }\end{array}$ & $\begin{array}{c}2 \\
\text { points }\end{array}$ & $\begin{array}{c}3 \\
\text { points }\end{array}$ & $\begin{array}{c}4 \\
\text { points }\end{array}$ \\
\hline Pronunciation & & & $*$ & & Pronunciation & & & $*$ & $*$ \\
\hline Vocabulary & & $*$ & & & Vocabulary & & & $*$ & \\
\hline Grammar & & $*$ & & & Grammar & & $*$ & & \\
\hline Fluency & & $*$ & & & Fluency & & & $*$ & \\
\hline
\end{tabular}

Table 4 The result of the 22 videos of student 1 in points

\begin{tabular}{|c|c|c|c|c|c|c|c|c|c|c|c|}
\hline Video & 1 & 2 & 3 & 4 & 5 & 6 & 7 & 8 & 9 & 10 & 11 \\
\hline points & 10 & 9 & 9 & 9 & 11 & 11 & 11 & 10 & 11 & 12 & 11 \\
\hline
\end{tabular}

\begin{tabular}{|l|c|c|c|c|c|c|c|c|c|c|c|}
\hline Video & 12 & 13 & 14 & 15 & 16 & 17 & 18 & 19 & 20 & 21 & 22 \\
\hline points & 10 & 11 & 10 & 10 & 11 & 12 & 11 & 11 & 12 & 11 & 11 \\
\hline
\end{tabular}

Table 5 The 22 videos'duration of student 2

\begin{tabular}{|l|l|l|l|l|l|l|l|l|l|l|l|l|l|}
\hline Video & 1 & 2 & 3 & 4 & 5 & 6 & 7 & 8 & 9 & 10 & 11 & 12 & 13 \\
\hline Dura- & 1.47 & 2.02 & 2.11 & 0.41 & 0.59 & 0.56 & 1.05 & 1.23 & 0.40 & 0.52 & 1.11 & 0.53 & 0.41 \\
tion & & & & & & & & & & & & & \\
\hline
\end{tabular}




\begin{tabular}{|l|l|l|l|l|l|l|l|l|l|}
\hline Video & 14 & 15 & 16 & 17 & 18 & 19 & 20 & 21 & 22 \\
\hline Duration & 1.58 & 1.05 & 0.58 & 1.20 & 1.17 & 0.43 & 1.07 & 1.22 & 1.54 \\
\hline
\end{tabular}

The first number indicates minute, the numbers after point indicates second.

e.g: 0.41 (41 seconds); $1.47(1$ minute, 47 second $)$

Table 6 The example of the videos in the rubric

Video 2

Video 3

\begin{tabular}{|c|c|c|r|r|r|r|r|r|r|}
\hline The Cagories & $\begin{array}{c}1 \\
\text { point }\end{array}$ & $\begin{array}{c}2 \\
\text { points }\end{array}$ & $\begin{array}{c}3 \\
\text { points }\end{array}$ & $\begin{array}{c}4 \\
\text { points }\end{array}$ & The Cagories & $\begin{array}{c}1 \\
\text { point }\end{array}$ & $\begin{array}{c}2 \\
\text { points }\end{array}$ & $\begin{array}{c}3 \\
\text { points }\end{array}$ & $\begin{array}{c}4 \\
\text { points }\end{array}$ \\
\hline Pronunciation & & & & $*$ & Pronunciation & & & & $*$ \\
\hline Vocabulary & & & $*$ & & Vocabulary & & & $*$ & \\
\hline Grammar & & & $*$ & & Grammar & & & $*$ & \\
\hline Fluency & & & $*$ & & Fluency & & & $*$ & \\
\hline
\end{tabular}

Table 7 The result of the 22 videos of student 2 in points:

\begin{tabular}{|c|c|c|c|c|c|c|c|c|c|c|c|}
\hline Video & 1 & 2 & 3 & 4 & 5 & 6 & 7 & 8 & 9 & 10 & 11 \\
\hline points & 12 & 13 & 13 & 12 & 13 & 12 & 12 & 12 & 12 & 12 & 13 \\
\hline
\end{tabular}

\begin{tabular}{|l|l|l|l|l|l|l|l|l|l|l|l|}
\hline Video & 12 & 13 & 14 & 15 & 16 & 17 & 18 & 19 & 20 & 21 & 22 \\
\hline points & 13 & 12 & 14 & 14 & 13 & 13 & 13 & 12 & 14 & 14 & 14 \\
\hline
\end{tabular}


Table 8 The 26 videos'duration of student 3 :

\begin{tabular}{|c|c|c|c|c|c|c|c|c|c|c|c|c|c|}
\hline Video & 1 & 2 & 3 & 4 & 5 & 6 & 7 & 8 & 9 & 10 & 11 & 12 & 13 \\
\hline $\begin{array}{c}\text { Duratio } \\
\mathrm{n}\end{array}$ & 2.15 & 0.51 & 0.25 & 0.50 & 0.33 & 0.38 & 0.40 & 0.43 & 0.39 & 0.51 & 0.43 & 0.36 & 0.43 \\
\hline
\end{tabular}

\begin{tabular}{|c|c|c|c|c|c|c|c|c|c|c|c|c|c|}
\hline Video & 14 & 15 & 16 & 17 & 18 & 19 & 20 & 21 & 22 & 23 & 24 & 25 & 26 \\
\hline $\begin{array}{c}\text { Duratio } \\
\mathrm{n}\end{array}$ & $\begin{array}{c}0.2 \\
9\end{array}$ & $\begin{array}{c}0.2 \\
0\end{array}$ & 0.45 & 1.13 & 1.19 & 1.13 & 1.04 & 0.37 & 0.31 & 0.35 & 0.56 & 1.05. & 1.11 \\
\hline
\end{tabular}

The first number indicates minute, the numbers after point indicates second.

e.g: 0.29 (29seconds); 1.04 (1 minute, 4seconds)

Table 9 The 26 videoswere inserted into the Rubric

Video 2

Video 3

\begin{tabular}{|l|l|l|l|l|l|l|l|l|l|}
\hline The Cagories & 1 & 2 & 3 & 4 & The Cagories & 1 & 2 & 3 & 4 \\
point & points & points & points & & point & points & points & points \\
\hline Pronunciation & & & $*$ & & Pronunciation & & $*$ & & \\
\hline Vocabulary & & & $*$ & & Vocabulary & & & $*$ & \\
\hline Grammar & & & $*$ & & Grammar & & $*$ & & \\
\hline Fluency & & & $*$ & & Fluency & & $*$ & & \\
\hline
\end{tabular}

Table 10 The result of the 26 videos of student 3 in points

\begin{tabular}{|l|c|c|c|c|c|c|c|c|c|c|c|c|c|}
\hline Video & 1 & 2 & 3 & 4 & 5 & 6 & 7 & 8 & 9 & 10 & 11 & 12 & 13 \\
\hline points & 10 & 12 & 9 & 9 & 10 & 11 & 9 & 11 & 10 & 10 & 11 & 9 & 11 \\
\hline
\end{tabular}




\begin{tabular}{|l|l|l|l|l|l|l|l|l|l|l|l|l|l|}
\hline Video & 14 & 15 & 16 & 17 & 18 & 19 & 20 & 21 & 22 & 23 & 24 & 25 & 26 \\
\hline Points & 10 & 11 & 9 & 11 & 10 & 10 & 10 & 10 & 10 & 10 & 10 & 10 & 11 \\
\hline
\end{tabular}

The result of the three students' videos can be seen in the graph below.

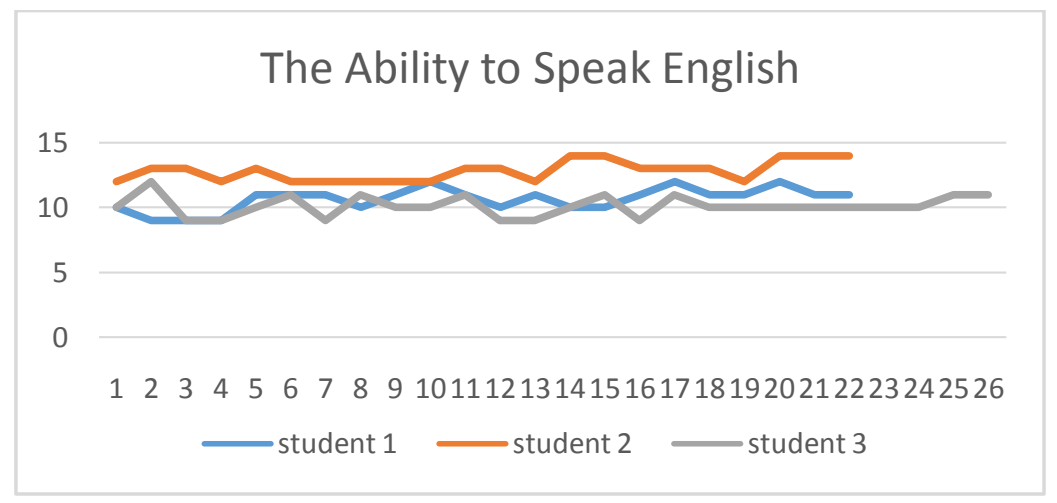

Figure 2 Horizontal line shows the number of videoswhile vertical line shows the points

Figure 2 shows that self learning through self recorded videos, the ability of students to speak English is fluctuated but in general we can see the improvement compared to the videos taken in the early semester. In the first four videos of student 1 , there is a decrease but the in the next videos, although they are fluctuated, the position are always above the first videos. In mid-semester there is a sharp increase but then decreases, and then fluctuates. In general, there is an improvement. Student 2 videos are all above the other two, but the same with the other two, the graph fluctuates. The last videos shows an increase. Compared to the first video, the last video increases significantly. The line graph of students 3 videos also fluctuates. In the second video there is a sharp increase but then decreases sharply. Students 3 ability to speak is considered about the same although there is an increase in the last video compared to the starting video. Although the three students videos show different increase but overall, the three students ability to speak English increses.

To see the highest improvent on the language category in five weeks, the result from the rubric was transferred into a graph below. 
The Graph of Student 1 Language Category improvement.

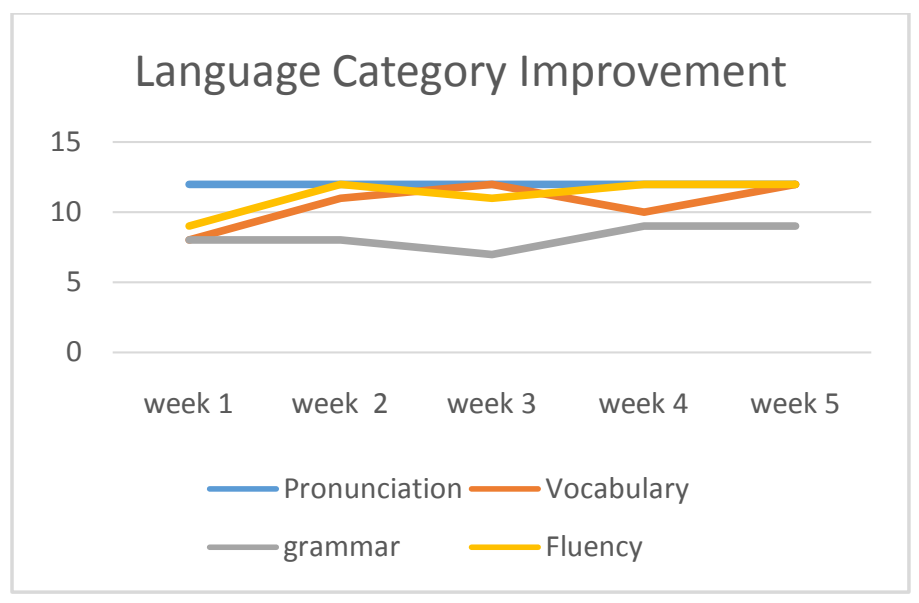

Figure 3 Student 1 Language Category Improvement

Figure 3 shows that vocabulary and fluency significantly improved. Student 1 did not have problems with pronunciation. The student speaks clearly and easy to understand. The lowest improvement was grammar. The improvement is not significant

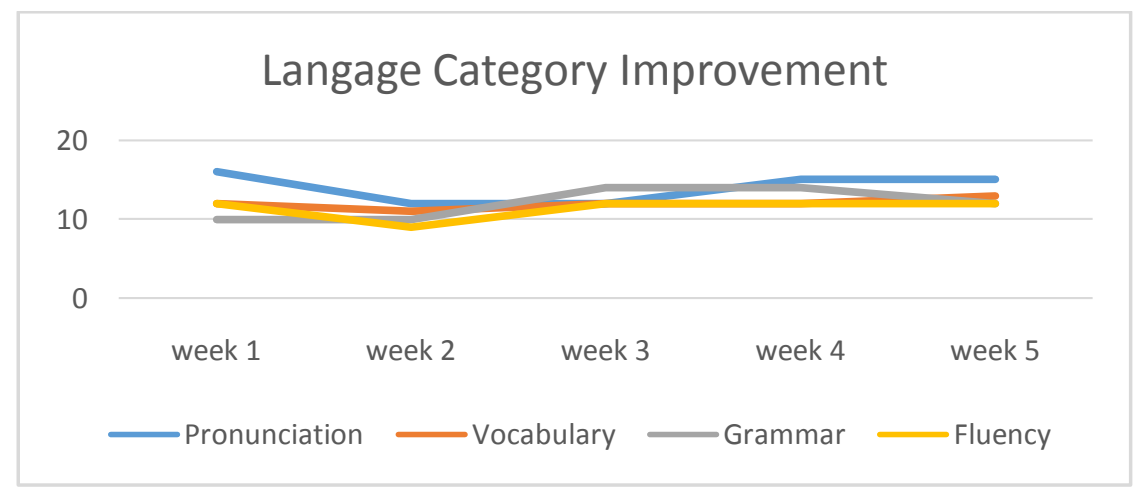

Figure 4 Student 2 Language Category Improvement

From figure 4, we can see that grammar improved significantly in week 3 but then in stayed the same until week 4 . From week 4 to 5 , there was a decrease but the position is above the first week. Fluency dropped in the second week but increased in the third week then stayed the same until week 5. There was a slight dropped of vocabulary in the second week but regained into the previous position until week 5. Pronunciation is 
quiet surprising since it dropped significantly. Although it managed to increase but the position was below week 1 .

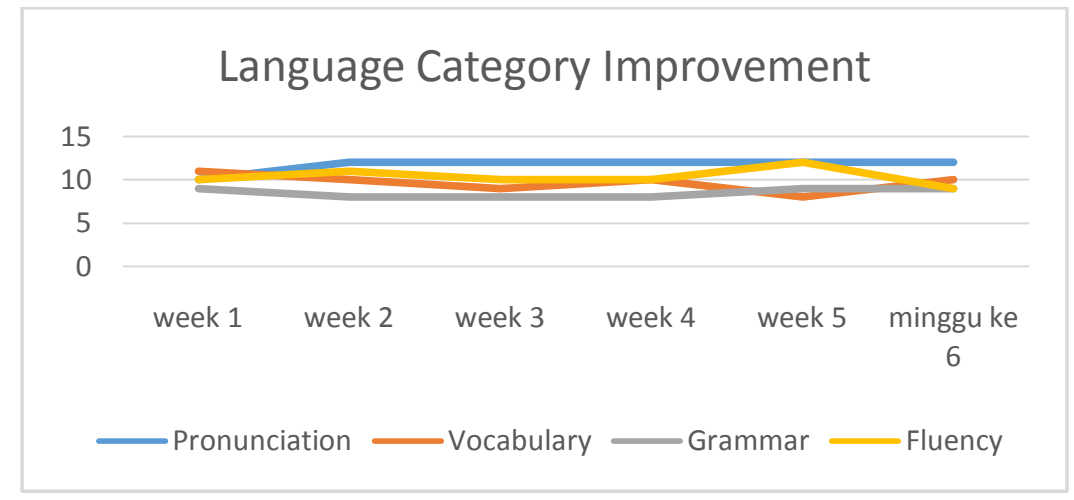

Figure 5 Student 3 Language Category Improvement

The language skill of student 3 that shows significant improvement is pronunciation. It improved two points in the second week and stayed in that position until week 6while other categories did not show any improvement.

\section{CONCLUSION}

From the results discussed above, it can be concuded that self learning, which one of them is through self recorded videos, can improve students' speaking skills. By recording what they speak in English, the students actively used English. From the sampel (the videos of the three students), there is improvement of the student's ability to speak English but the category of the language skills improved varied. One students improved more in his/her pronunciation, while others in other skills (either vocabulary, grammar, or fluency). No matter what category they improved, all support them to speak English.

Language, especially foreign language, needs to be used if we want to keep the language. If the students feel shy to speak or have not enough confidence, self recorded video is a good for them as this practice done by oneself and does not invove others. When they get used to speak English, their confidence will increase and they will be ready to speak with others.

This research was carried out by taking three students' videos as the sample in which the duration is 45 minutes to three minutes five seconds. To get a more 
valuable data, it is advisable for the lecturers to ask their students to make the video not less than one minute, especially in the videos after the first weeks.

\section{REFERENCES}

DeFranzo, S. E. (2011) retrieved from https://www.snapsurveys.com/blog/qualitativevs-quantitative-research/

Gillis. G ( 2013) in Communicationscommunication skills, effective communication, Gerald Gillis, importance of speaking skills, public speaking, speaker, speaking skillsretrieved from http://www.geraldgillis.com/importance-speaking-skills/

Hughes, R. 2010. Materials to develop the speaking skills, in N. Narwood (Ed.). English language teaching materials: theory and practice.Cambridge: Cambridge University Press.

Hunter, J. 2012. 'Small Talk': developing fluency, accuracy, and complexity in Speaking,

ELT Journal66(1): 30-41 [online].

McNulty, A., and Lazarevic, B. (2012). Best practices in using video technology to promote second language acquisition. Teaching English with Technology, 12 (3), pp. 49-61.

Merriam, S., B. (2009). Qualitative research: A guide to design and implementation. San Francisco: Jossey Bass Willey Imprint

Orlova, N. (2009). Video Recording as a Stimulus for Reflection in Pre-Service EFL Teacher Training. English Teaching Forum, no. 2, 30-35.

Patil, Z.N. (2008). Rethinking the objectives of teaching English in Asia. Asian EFL Journal.10 (4), 227-240.

Raine, P (2011). Promoting speaking fluency. Retrieved fromTEFL Jouney, October 8, 2011.

Robertson, K. (2009) retrieved fromhttp://www.readingrockets.org/article/five-thingsteachers-can-do-improve-learning-ells-new-year 
Trent, J. (2009). Enhancing oral participation across the curriculum: Some lessons from the EAP classroom. Asian EFL Journal, 11(1), 256-270.

Verner, S. (2017) retrieved fromhttp://busyteacher.org/4836-how-to-evaluatespeaking.html

Zaremba, A. J. (2006). Speaking professionally. Canada: Thompson South-Western.

Zhang, Y. (2009). Reading to speak: Integrating oral communication skills. English Teaching Forum,47(1), 32-34. 